\title{
Relationship between thermo-hygrometric variations and the maturity of dates in Biskra (Case of Deglet Nour)
}

Mohammed Faci \& Salah Eddine Benziouche

Mohammed Faci : Division Ecologie des Ecosystèmes Arides et les Risques Climatiques, Biskra, Algérie. faci.mohammed@crstra.dz

Salah Eddine Benziouche : Université Mohamed Khider, Biskra, Algérie.

DOI: $10.25518 / 2295-8010.1898$

Résumé :

Relation entre les variations thermo-hygrométriques et la maturité des dattes à Biskra (Cas Deglet Nour)

La variation des conditions climatiques a un impact direct sur la croissance des plantes et sur le rendement des cultures, tant en qualité qu'en quantité. Ces dernières années, de nombreuses études ont prouvé l'hypothèse du réchauffement climatique. Dans ce contexte, l'étude du comportement des plantes cultivées est devenue une nécessité, afin de garantir la sécurité alimentaire des populations. Notre contribution porte sur l'influence de la température et de l'humidité relative de l'air sur le cycle de développement des dattes Deglet Nour à Biskra. Pour atteindre nos objectifs, nous avons suivi le cycle phénologique du palmier dattier, cultivar Deglet Nour, pendant deux années (2018 et 2019). En même temps, des enregistreurs thermohygrométriques ont été installés à l'intérieur des palmeraies de Lichana et d'El-Kantara. Enfin, nous avons calculé l'accumulation thermique et le temps nécessaire à la maturation des dattes. Les dattes Deglet Nour, dans la wilaya (province) de Biskra, ont besoin d'une accumulation thermique d'environ 3450-4250 ${ }^{\circ} \mathrm{C}$ pour mûrir, ce qui équivaut à une durée de 30-44 semaines. Les résultats montrent que la température et l'humidité de l'air ont tendance à augmenter, alors que les dates d'apparition et d'ouverture des spathes et de la maturité des fruits sont devenues plus précoces.

Mots-clés : thermo-hygromètre, dates, Deglet Nour, Algérie

\section{Abstract :}

Variations in climatic conditions have direct impacts on plant growth and crop yields, both in quality and quantity. In recent years, many studies have proven the hypothesis of global warming. In the context of climate change, the study of the behavior of cultivated plants has become a necessity, in order to guarantee the food security of the populations. Our contribution focuses on the influence of temperature and relative air humidity on the development cycle of Deglet Nour dates in Biskra. To achieve our objectives, we followed the phenological cycle of the date palm, cultivar Deglet Nour, for two years (2018 and 2019). At the same time, thermohygrometric recorders were installed inside the palm groves of Lichana and El-Kantara. Finally, we calculated the thermal accumulation and the time required for the dates to ripen. Deglet Nour dates, in the wilaya (province) of Biskra, require a thermal accumulation of approximately $3450-4250^{\circ} \mathrm{C}$ to ripen, equivalent to $30-44$ weeks. The results show that air temperatures and humidity have been trending upwards. The dates of the appearance and opening of the spathes 
Relationship between thermo-hygrometric variations and the maturity of dates ...

have become earlier and the same for the maturity of the fruits.

Keywords : thermo-hygrometer, dates, Deglet Nour, Algeria

\section{Introduction}

Due to the long history of date cultivation and the great distribution and exchange of dates, the exact origin of the date palm is unknown, but probably comes from ancient Mesopotamia (southern Iraq) or western India (22). From its centre of origin, date cultivation spread to the Arabian Peninsula, North Africa and the Middle East. The spread of date culture later accompanied the expansion of Islam and reached southern Spain and Pakistan. The Spaniards were the first to introduce date palms to America (14).

The date palm (Phoenix dactylifera L.) has been cultivated in North Africa for at least 5000 years (25). According to Zaid (2010) (23), favourable latitudes for date palm cultivation in Algeria, are between $24^{\circ} \mathrm{N}$ and $34^{\circ} \mathrm{N}$.

Although the date palm can grow in a wide geographical area, specific conditions are required for flowering and good fruit development. Prolonged summer heat promotes fruit ripening, while rain and high humidity cause cracking, blackening, fermenting and mould development (4).

Biotic processes promote phenological convergence, the strength of these processes can determine the sharpness of the peak, while climatic factors can determine its timing. It is therefore essential to consider the influences of climate on phenology (21).

These last years, many studies talk about global warming; while scientists and politicians discuss, always, whether it is climate variability or climate change.

Climate variability refers to variations in mean state and other climate statistics (standard deviations, occurrences of extremes ...) at all scales, temporal and spatial. It can result from natural internal processes within the climate system (internal variability) or variations of natural or anthropogenic external forces (external variability). In contrast, climate change refers to any change in the climate over time, whether due to natural variability or anthropogenic forces (18).

Any modification of the annual climate cycle has repercussions on the vegetative development of plants. The impacts differ according to the species and the geo-pedo-climatic characteristics of each region. Nevertheless, water deficit causes deterioration of yields and quality of agricultural products, especially in the Sahara (3).

Monitoring the phenological cycle of date palm, the main axis of the oasian ecosystem and agriculture in the Sahara, becomes a necessity to see if this change (or variation) climate has an influence on dates. Our research fits into this framework, which aims to, essentially, to know the impact of certain metrological parameters (air temperature and humidity) on the maturity of dates « Deglet Nour » in Biskra; potentially phœnicicultural region in Algeria, in quantity and quality, in particular by the famous variety « Deglet Nour». 


\section{Materials and methods}

\section{Study region}

The wilaya (province) of Biskra is located in the South-East of Algeria, South of the Aurès mountains, it appears as a real buffer space between the North and the South (Figure 1), its surface area is $21671.2 \mathrm{~km}^{2}(2,5)$.

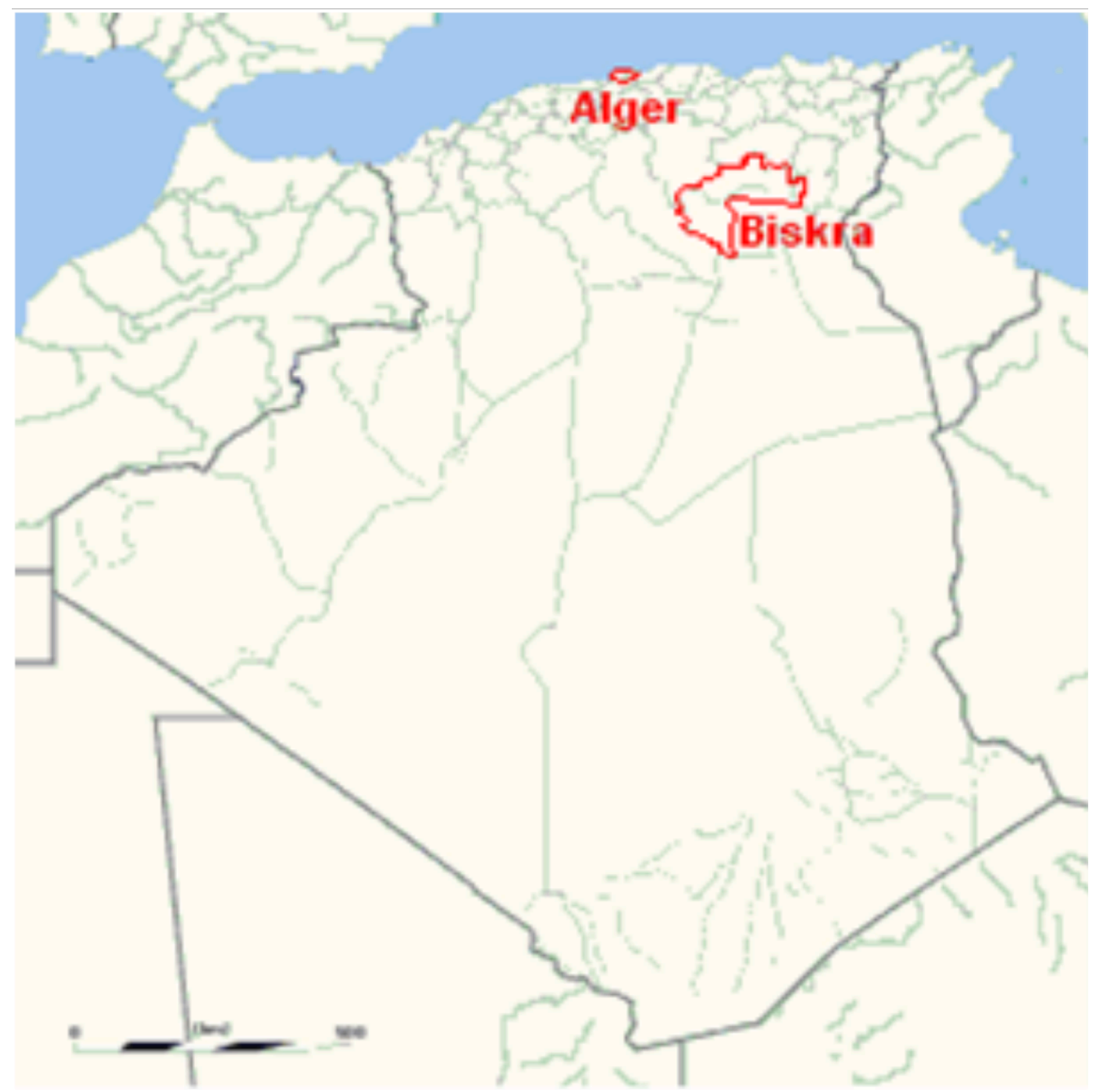

Figure 1: Location of the wilaya of Biskra on the map of Algeria.

With a total agricultural area of 1652751 ha, including 185473 ha represents the useful agricultural area, Biskra is a leading agricultural wilaya with thousands of hectares dedicated to vegetable crops, fruit and date palm cultivation. The heritage of date palm in the wilaya of Biskra is rich, more than 4.6 million palm trees, including more than 2.6 million from the famous Deglet Nour 
Relationship between thermo-hygrometric variations and the maturity of dates ...

(i.e. more than $56 \%$ of total palm trees in the wilaya). The cultivation of date palm has continued to evolve over the last two decades, its area has increased from 23700 ha at the beginning of this millennium (in 2000) to 43617 ha in 2018. Also, production is increased, from 0.93 to 4.6 million quintals, during the same period $(2,5)$.

For our study, we chose two palm groves (Figure 2).

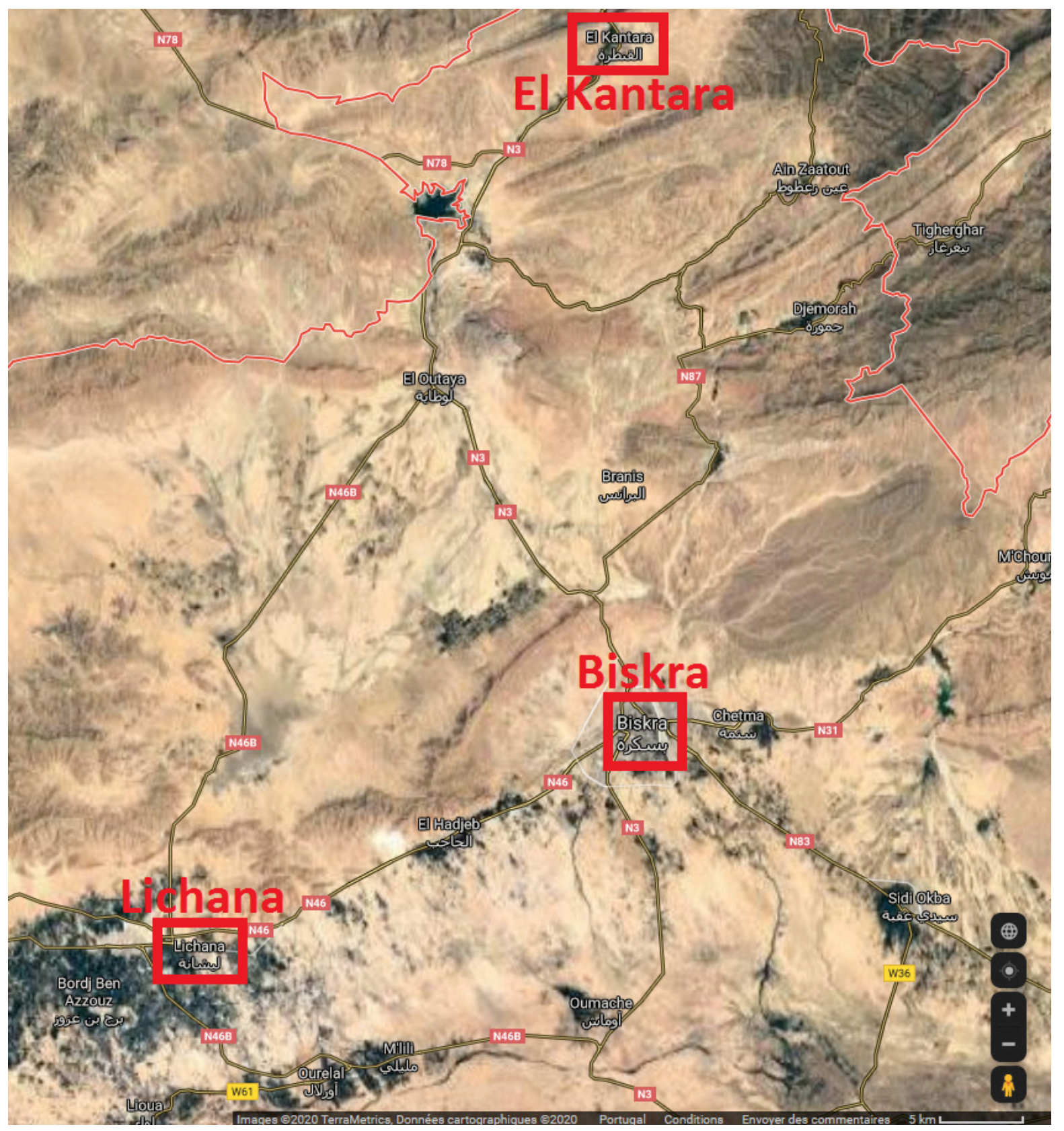

Figure 2: Study areas.

- El-Kantara, located in the South of the Aurès foothills, about $50 \mathrm{~km}$ North of the capital of the wilaya. It is an area with a low phœnicicultural heritage, the area occupied by date palms does not exceed 232 ha (5). 
- Lichana, located in the plains, $30 \mathrm{~km}$ South-West of Biskra and at $5 \mathrm{~km}$, only, of Tolga. This municipality contains 1411 ha cultivated by the date palm. The palm groves of Lichana are interfering with the palm groves of the municipality of Tolga; potential phoenicultural region from a quality (5).

\section{Plant material}

The date palm (Phoenix dactylifera L.) is a species of arid and semi-arid regions, it is a thermophilic species. Its temperature requirements, especially during the fruiting period, are very high. The vegetative activity of the date palm starts at a temperature between $7^{\circ} \mathrm{C}$ and $10^{\circ} \mathrm{C}$, depending on the individual, cultivars and local climatic conditions. This activity reaches its maximum between $30^{\circ} \mathrm{C}$ and $38^{\circ} \mathrm{C}$. A good production of dates, quantitatively and qualitatively, can only be obtained if the date palm benefits from a well-defined sum of temperatures $(13,15,20)$. The thermal requirements of the different varieties, during the fructification, vary according to date categories. In general, dry and late varieties have requirements in excess of $3500^{\circ} \mathrm{C}$, semi-dry and seasonal varieties have thermal requirements ranging from $2500^{\circ} \mathrm{C}$ to $3500^{\circ} \mathrm{C}$. Thermal requirements of soft varieties vary from $2000^{\circ} \mathrm{C}$ to $2500^{\circ} \mathrm{C}(1)$.

The plant material observed during our study is the cultivar 'Deglet Nour', considered a late maturing variety (taking longer to ripen). This variety represents more than $45 \%$ of the date palm production in Algeria, of which more than 27\% of Deglet Nour's palm trees are cultivated in the territory of Biskra wilaya $(5,16)$. Deglet Nour, characterized by its tenderness and golden appearance of the pulp, is among the rare varieties that can be marketed on a large scale in Algeria and exported all over the world (8).

\section{Phenological cycle}

The annual cycle of the plants is punctuated by the alternation of dry and wet seasons. It therefore corresponds to the sequence of phenological states through which the plant passes before returning to an initial state. Thus, in temperate zones, it is the state of winter rest that signals the end of the phenological cycle of plants, which is broadly defined on the vegetative dimension of development.

The phenological cycles of temperate species will thus be called annual $(9,11)$.

In general, the date passes through five stages $(12,16)$ :

- Knotted fruit stage (Loulou), it begins after one to two weeks of fertilization, the colour of the carpel turns green, pear-shaped. It lasts between 4 and 5 weeks.

- Green date stage (Khalal), The duration of this stage is about seven weeks, it is dependent on climatic conditions. The ovary slowly increases in size, until it reaches the size of a pea.

- Rotating date stage (Bser), 3 to 5 weeks, during this stage the date takes on its spherical shape.

- Early ripening stage (Routab), 2 to 4 weeks, when the date begins to ripen.

- Mature date stage (Tmar), the fruit becomes concentrated in sugar.

This contribution presents the observations recorded over two years (2018-2019), concerning the development of Deglet Nour dates in the study area, and the effects of extreme weather events; 
Relationship between thermo-hygrometric variations and the maturity of dates ...

exceptionally the temperature and humidity of the air on these different stages of the fruit of this cultivar and also the appearance of diseases.

\section{Air temperature and relative humidity data}

We installed two temperature and relative humidity sensors in two palm groves (El-Kantara and Lichana). By using an instrument for measuring and registering the trademark EXTECH (RHT10). Check-in was provided 24 hours a day, during the two years of observation.

On the other hand, we used climatic data from the Biskra station of the National Meteorological Office (ONM), for the period 1988-2017, to compare thermo-hygrometric variation.

\section{Calculation of thermal cumulation}

For the calculation of the thermal cumulation required for date maturity, we calculated the accumulation of degree-days, according to the following formula (10):

Degree-day $=[(T \max +\mathrm{T} \min ) / 2]-\mathrm{T}$ base

T max : maximum daily temperature.

T min : minimum daily temperature.

$\mathrm{T}$ base : temperature at which the plant resumes its vegetative activity.

In general, the temperatures necessary for the resumption of vegetative activity of the plants vary from 7 to $10^{\circ} \mathrm{C}(10)$. In this contribution we conceded that the base temperature is $10^{\circ} \mathrm{C}$.

\section{Statistical analysis}

The effects of climatic parameters on the evolution of Deglet Nour dates were analysed by Multivariate Analysis of Variance. MANOVA is a statistical test that aims to determine whether qualitative factors have significant effects on several quantitative dependent variables taken together. At the same time, MANOVA is therefore a generalization of analysis of variance (ANOVA), which is univariate, that is to say which relates to only one dependent variable. MANOVA is also used to identify interactions between dependent variables and between independent variables. Calculations and statistical modelling were carried out using SPSS Statistics software 20.

\section{Results and discussion}

\section{Average air temperature in study areas}

The average air temperature, in this study, is the average of the monthly sum of daily maximum temperatures and daily minimum temperatures (Figure 3 ).

In the study areas, January and December are the coldest months of the year (minus $12^{\circ} \mathrm{C}$ ), while July and August are the hottest months of the year (more than $34^{\circ} \mathrm{C}$ ). 


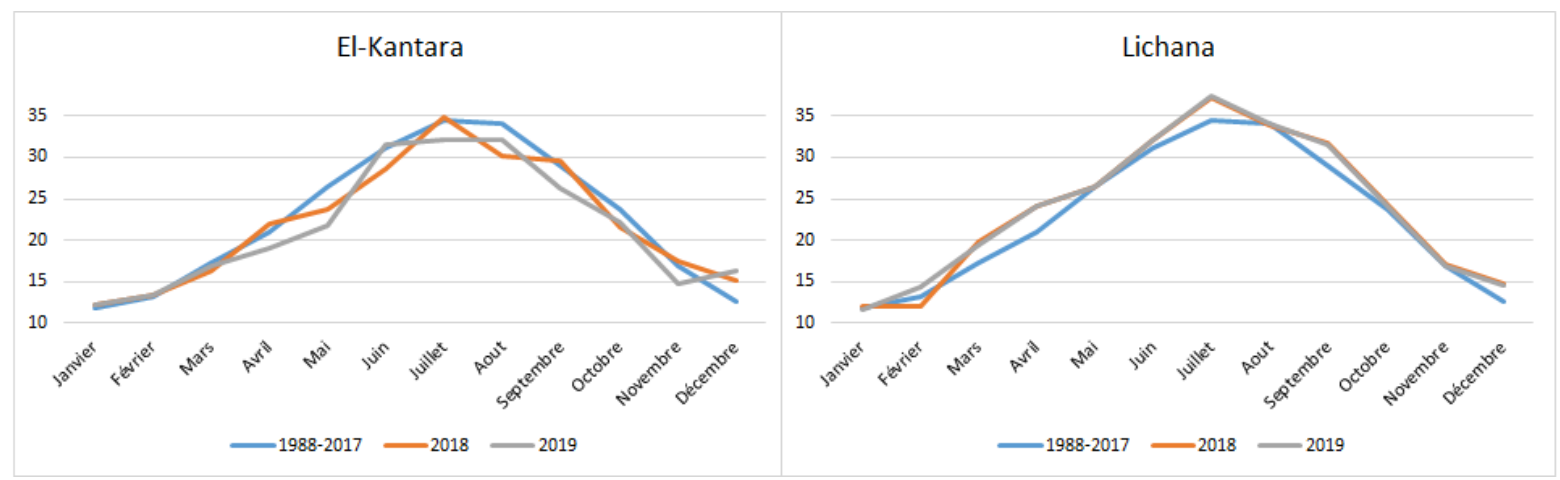

Figure 3: Comparison between the average air temperature $\left(\right.$ in ${ }^{\circ} \mathrm{C}$ ) inside the palm groves of El-Kantara and Lichana and the average recorded in Biskra (1988-2017).

Source : Our recordings $+(17)$.

It emerges, in general, that the air temperature inside the palm grove of El-Kantara is lower than the average recorded during the reference period (1988-2017); the data for this reference period are those recorded at the meteorological station of the ONM, in Biskra (17). On the other hand, the temperatures in the Lichana palm grove are higher compared to the same period of the same reference. They exceed $37^{\circ} \mathrm{C}$ in July.

\section{Relative air humidity in study areas}

After obtaining the recorded relative air humidity data, we calculated the daily average (the average of 24 measurements recorded each day). Then we calculated the monthly average in each palm grove.

In general, the humidity level inside the two palm groves is higher than the reference average (17). It reaches its maximum during the cold period and its minimum in summer. The highest and lowest rates are recorded in El-Kantara, 65,84\% and 25,73\% respectively (Figure 4).

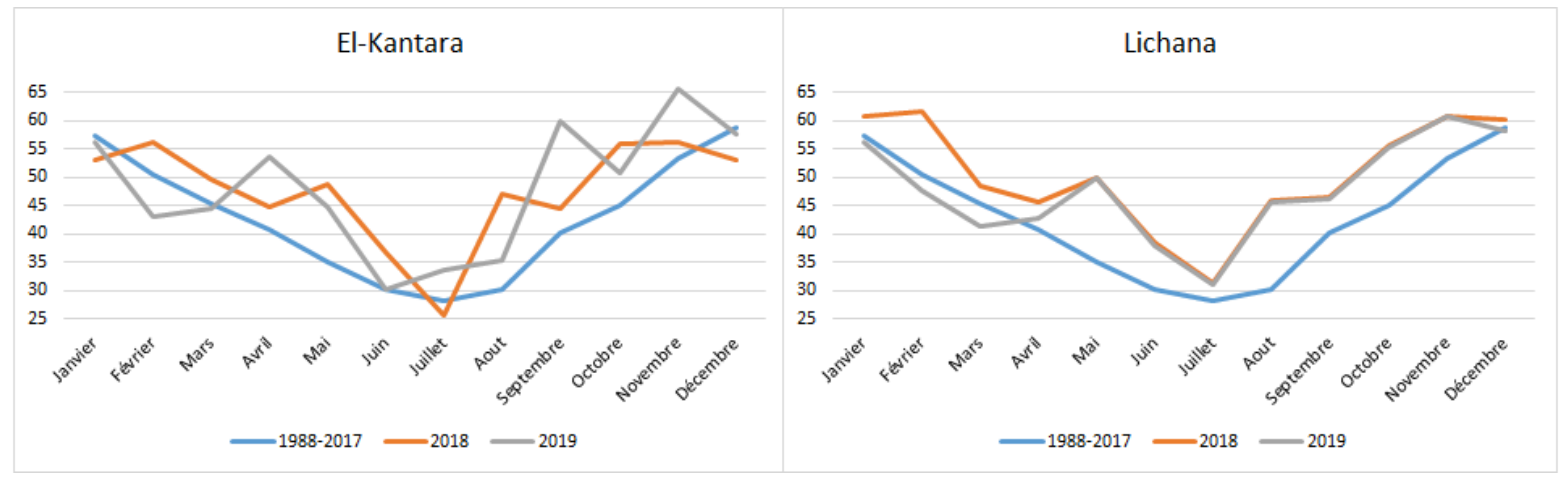

Figure 4: Comparison between the average relative humidity of the air (in\%) inside the palm groves of El-Kantara and Lichana and the average recorded in Biskra (1988-2017).

Source : Our recordings $+(17)$. 


\section{Deglet Nour phenological cycle in the study areas}

During the two years (2018-2019), we recorded the dates of the beginning of the main phenological stages of Deglet Nour (Tables 1 and 2), through a weekly monitoring of three palm trees in each palm grove (El-Kantara and Lichana). Palm trees have the same morphological characteristics (size and vigour).

Every year, the palms of the same palm grove are pollinated during the same day.

The start of the various stages followed, namely: the appearance and opening of inflorescences, pollination, fruit set, maturity and even the date of harvest, always ahead in the Lichana palm grove. In 2018, we recorded in El-Kantara a two-month delay in the appearance of inflorescences, compared to the first palm grove. The appearance of inflorescences in Lichana begins in the last week of January, in contrast, it is at the end of February in El-Kantara.

Table 1: Dates of the beginning of the phenological stages from Deglet Nour to El-Kantara.

\begin{tabular}{|c|c|c|c|c|c|c|c|}
\hline \multirow[t]{2}{*}{ Years } & \multicolumn{7}{|l|}{ Stages } \\
\hline & $\begin{array}{l}\text { Appearance of } \\
\text { inflorescences }\end{array}$ & $\begin{array}{l}\text { Opening of } \\
\text { inflorescences }\end{array}$ & Pollination & $\begin{array}{l}\text { Fruit } \\
\text { set }\end{array}$ & $\begin{array}{l}\text { Early } \\
\text { maturity }\end{array}$ & $\begin{array}{l}\text { End of } \\
\text { maturity }\end{array}$ & Harvest \\
\hline 2018 & March 29 & April 08 & April 15 & Jul 02 & Sep 25 & Oct 20 & Nov 15 \\
\hline 2019 & Feb 28 & March 27 & April 06 & Jul 05 & Oct 10 & Oct 25 & Nov 09 \\
\hline
\end{tabular}

Table 2: Dates of the beginning of the phenological stages from Deglet Nour to Lichana.

\begin{tabular}{|c|c|c|c|c|c|c|c|}
\hline \multirow[t]{2}{*}{ Years } & \multicolumn{7}{|l|}{ Stages } \\
\hline & $\begin{array}{l}\text { Appearance of } \\
\text { inflorescences }\end{array}$ & $\begin{array}{l}\text { Opening of } \\
\text { inflorescences }\end{array}$ & Pollination & $\begin{array}{l}\text { Fruit } \\
\text { set }\end{array}$ & $\begin{array}{l}\text { Early } \\
\text { maturity }\end{array}$ & $\begin{array}{l}\text { End of } \\
\text { maturity }\end{array}$ & Harvest \\
\hline 2018 & Jan 27 & March 05 & March 10 & Jun 10 & Sep 10 & Oct 10 & Nov 10 \\
\hline 2019 & Feb 01 & March 08 & March 12 & Jun 15 & Sep 12 & Oct 15 & Nov 06 \\
\hline
\end{tabular}

\section{Duration and thermal requirements of the maturity of Deglet Nour dates in the study areas}

The results obtained show that the time required for the development of Deglet Nour dates, until total maturity, in the Lichana palm grove does not exceed 33 weeks (Figure 5). On the other hand, in El-Kantara the date of the same cultivar needs up to 44 weeks to reach full maturity (Figure 6).

During its development cycle, the Deglet Nour date in Lichana, receives between $4149^{\circ} \mathrm{C}$ and $4234^{\circ} \mathrm{C}$ as cumulative air temperatures; while the sum of this meteorological indicator does not exceed $3574^{\circ} \mathrm{C}$, for Deglet Nour palms, in the palm grove of El-Kantara. 


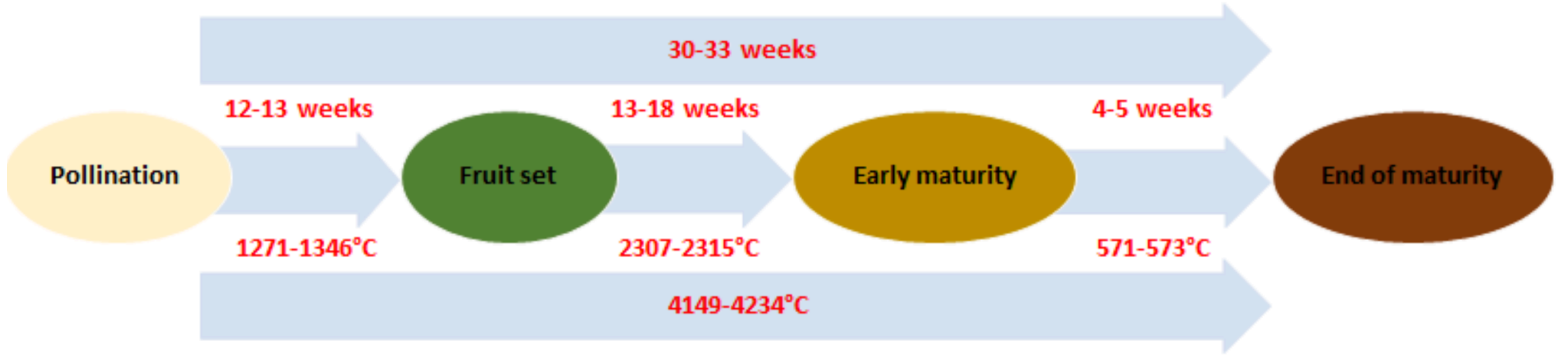

Figure 5: Duration and thermal requirements of dates maturity from Deglet Nour to Lichana.

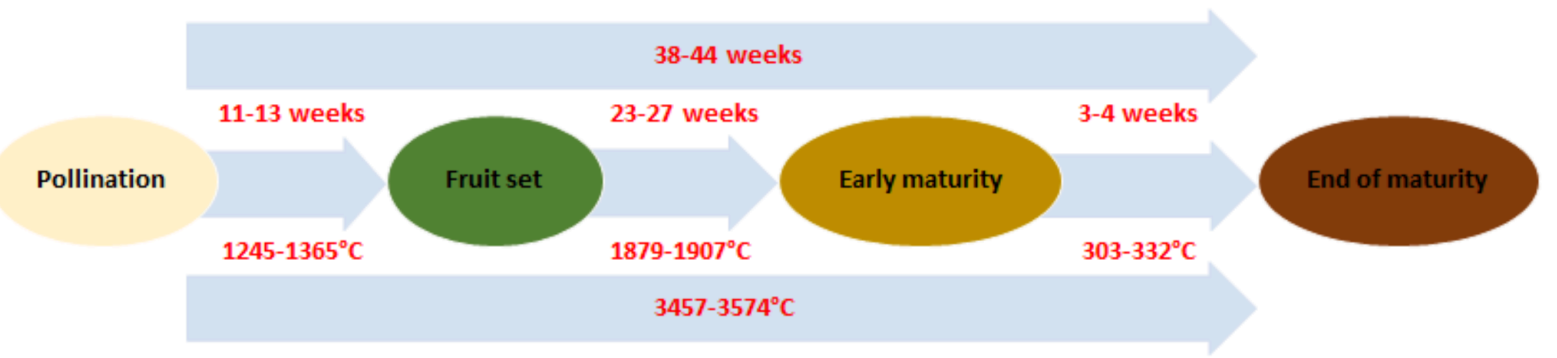

Figure 6: Duration and thermal requirements of dates maturity from Deglet Nour to ElKantara.

\section{Statistical analysis results}

Statistical analysis of the results showed that thermal cumulation has an influence on the start dates of the phenological stages from Deglet Nour to Biskra. In fact:

1- There is a significant effect of the interaction between Years and Palm Groves ( $p=0.027)$, but no significant effect for years or palm groves alone on all variables studied.

2- The interaction (Years x Palm Groves) affected only the thermal requirements of the PollinationFruit set $(p=0.027)$ and Fruit set-Early maturity $(p=0.010)$. The effect (Palm Groves) affected the periods of Fruit set-Early maturity $(p=0.015)$ and Early maturity-End of maturity $(p=0.038)$.

For the start dates of the phenological stages, there is a significant effect of the interaction (Years $x$ Palm Groves $)$ on the Fruit set $(p=0.033)$ and on the Early maturity $(p=0.036)$.

On the other hand, we recorded no significant effect for the duration of the phenological stages.

\section{Discussion}

Air temperature on a farm, varies from one area to another. This variation depends on several factors, such as: geographical location, altitude, sun exposure, and also planting density. In our study, planting and sun exposure characteristics are similar in the two palm groves, where we did our follow-up. However, the geographical coordinates are different; the two zones are, in the East, on the longitudinal line $5^{\circ} 25^{\prime}$ for Lichana and $5^{\circ} 42^{\prime}$ for El-Kantara. The two farms are located in the northern hemisphere of the globe, Lichana with a latitude of $34^{\circ} 43^{\prime}$ and El-Kantara at $35^{\circ} 12^{\prime}$. 
Relationship between thermo-hygrometric variations and the maturity of dates ...

But, with an altitude of about 500 metres above sea level, the palm grove of El-Kantara is higher than that of Lichana $(+156 \mathrm{~m})$.

Thus enumerated, geographic coordinates and site altitude determine air temperature variation. As a result, the average air temperatures recorded inside the Lichana palm grove are higher (more than $2^{\circ} \mathrm{C}$ ), throughout the year, compared to what was recorded in El-Kantara.

The air temperature has a significant impact on the date palm's vegetative activity. In Lichana, where we recorded temperatures higher than the reference average (up to $5^{\circ} \mathrm{C}$ ), during the period 1988-2017, the date of appearance of the first inflorescences (males and females) is 4 to 9 weeks earlier than that recorded at El-Kantara. This directly affects the early stages of development of dates from Deglet Nour to Lichana, from fruit set to full fruit maturity.

The ideal temperature for the growth of the date palm (all cultivars combined), during the period from pollination to fruit ripening, frequently varies between $21^{\circ} \mathrm{C}$ to $27^{\circ} \mathrm{C}$ on average (24). During the same period of the phenological cycle of the cultivar Deglet Nour, the records we obtained indicate that the average temperature at El-Kantara varies between $25.25^{\circ} \mathrm{C}$ and $25.86^{\circ} \mathrm{C}$, while it is between $28.66^{\circ} \mathrm{C}$ and $28.71^{\circ} \mathrm{C}$, respectively in 2019 and 2018 .

On the other hand, thermal cumulation (degree-days) affects the duration of fruit maturity. Indeed, high temperatures during the winter period (January-February) cause the early and opening of the inflorescences of the date palm, while summer temperatures (June-July-August) determine the maturity period of Deglet Nour dates. It should be noted that from the late 1980s onwards, air temperatures, whether minimum or maximum, experienced an upward trend during the warm season $(6,7)$.

The thermal sum recorded at Lichana $\left(4149^{\circ} \mathrm{C}\right.$ to $\left.4234^{\circ} \mathrm{C}\right)$, effect on the duration of the development stages of the dates, it allows the dates of this palm grove to begin the maturity stage before the dates of the El-Kantara palm grove (between $3457^{\circ} \mathrm{C}$ and $3574^{\circ} \mathrm{C}$ ). In addition to this, Deglet Nour requires between 30 and 33 weeks to reach full maturity in Lichana gardens, while she needs 38 to 44 weeks in El-Kantara. Néanmoins, this duration is longer compared to studies carried out in the early 1970s. It was around 200 days (13).

On the other hand, the date palm requires optimal humidity. If it's strong during flowering, it causes the decay of the inflorescences and hinders the pollination process. On the other hand, during ripening, dates become soft when ripening in a humid atmosphere, while they become dry when humidity is low (19).

In our study, the relative humidity of the air is generally high during the cold season (DecemberJanuary). It is between $42 \%$ to $65 \%$ in El-Kantara and between $50 \%$ to $60 \%$ in Lichana. Low humidity levels are recorded during the summer (June-July-August), period of fruit growth and maturity, they vary between $25 \%$ to $47 \%$ in El-Kantara and from $31 \%$ to $46 \%$ in the Lichana palm grove.

The annual average humidity recorded inside the Lichana palm grove was $50.54 \%$ and $47.80 \%$, respectively in 2018 and 2019. While, during the same period, we recorded $47.65 \%$ and $47.99 \%$ in El-Kantara. These rates are higher than the average recorded in Biskra in the early 1970s of the last century, which was around $43.5 \%$ (19). 


\section{Conclusion}

The humidity inside the palm groves is higher than outside; hence the feeling of freshness, especially during the warm season. Monthly average relative air humidity, in the palm groves of the study area (El-Kantara and Lichana), varies between $25.73 \%$ and $65.84 \%$. It reaches its maximum during the cold season, while the minima are recorded during the hot season.

Recorded air temperatures are higher throughout the year in Lichana, compared to El-Kantara data, this is probably due to the high altitude of the last palm grove. This temperature deference allows the early appearance and opening of inflorescences from Deglet Nour to Lichana. Precocity can happen up to two months.

The thermal accumulation (degree-days), during the period from pollination until maturity of Deglet Nour dates, varies between $3457^{\circ} \mathrm{C}$ and $4234^{\circ} \mathrm{C}$. It's superior in the palm grove of Lichana. This factor explains the lengthening of fruit formation and date maturity in the El-Kantara palm grove. In general, Deglet Nour cultivar dates, in Biskra, need 30 to 44 weeks to reach full fruit maturity.

\section{Acknowledgements}

At the end of this modest contribution, I must warmly thank my colleagues who helped me with the follow-up in the field. I quote among others: HAFNAOUI M.A, BENSAID M and AZZOUZ R. As I also thank Dr NIA B, Mr HAFNAOUI O, Mr CHRIF A and all the farmers who gave me access to their palm groves.

\section{Bibliographie}

1. Babahani S. \& Eddoud A., 2012, Effet de la température sur l'évolution des fruits chez quelques variétés du palmier dattier (Phoenix dactylifera L.). Algerian journal of arid environment, 2(1), 36-41.

2. Benaziza A. \& Makhloula S., 2020, Etude des performances de quelques variétés d'abricotier (Prunus armeniaca L.) dans les oasis du Sahara algérien. Agrobiologia, 10(1), 1813-1825.

3. Benziouche S.E. \& Chehat F., 2019, Irrigation problem in Ziban oases (Algeria): causes and consequences. Environment, Development and Sustainability, 21(6), 2693-2706.

4. Burt J., 2008, Growing date palms in Western Australia. Food Western Australia. Government of Western Australia, Australia, 4 p.

5. Direction des Services Agricoles de la Wilaya de Biskra (DSA-Biskra)., 2018, Rapport Final sur le Secteur Agricole. Service Statistique de la Direction des Services Agricoles de la Wilaya de Biskra, Biskra, Algeria, 62 p.

6. Faci M., Matari A., Oubadi M. \& Farhi Y., 2016, Analyse des journées de forte chaleur en Algérie. ACTES du $29^{e}$ Colloque de l'Association Internationale de Climatologie, Besançon, France, 261-266.

7. Faci M., Oubadi M., Matari A. \& Farhi Y., 2018, Heat waves in Algeria: A potential risk. International Journal of Innovative Technical and Applied Sciences, 2(1), 13-21. 
Relationship between thermo-hygrometric variations and the maturity of dates ...

8. Fedala N., Mokhtari M. \& Mekimene L., 2020, Contribution à la valorisation des dattes (Deglet-Nour) dans la fabrication du fromage de chèvre. Agrobiologia, 10(1), 1918-1928.

9. Fournier A., 1991, Phénologie, croissance et production végétales dans quelques savanes d'Afrique de l'Ouest ; Variation selon un gradient climatique. ORSTOM, Paris, France, 312 p.

10. Herms D.A., 2004, Using degree-days and plan phenology to predict pest activity. In: IPM (Integrated Pest Management) of Midwest Landscapes. CFANS., University of Minnesota, USA, pp 49-59.

11. Mangenet T., 2013, Approche rétrospective des cycles phénologiques chez quelques espèces guyanaises; Vers une nouvelle branche de la dendrochronologie ?. Dissertation, University of Montpellier 2, France, 200 p.

12. Meliani S., 2017, Etudes morphogénétique et cytogénétique de l'appareil reproducteur du palmier dattier (Phoenix dactylifera L.) ; Cultivar 'Takerbucht'. Dissertation, University of Oran 1, Algeria, 198 p.

13. Munier P., 1973, Le palmier dattier. Maison-neuve et Larose, Paris, France, 217 p.

14. Nixon R.W., 1951, The date palm: "Tree of Life" in the subtropical deserts. Econ Bot., 5, 274-301.

15. Nixon W.R. \& Carpenter J.B., 1978, Growing dates in the United States. Agri Info Bull., 207, 21-23.

16. Observatoire National des Filières Agricoles et Agroalimentaires (ONFAA)., 2016, Suivi de campagne phœnicicole. Note de conjoncture $\mathrm{N}^{\circ} 1$, ONFAA, Alger, Algeria, 5 p.

17. Office National de la Météorologie (OMM)., 2018, Résumés annuels du temps en Algérie. ONM, Alger, Algeria, 112 p.

18. Ramamasy S. \& Baas S., 2007, Climate variability and change: adaptation todrought in Bangladesh. A resource book and training guide. Asian Disaster Preparedness Center, FAO, Rome, Italy, 56 p.

19. Toutain G., 1977, Origine, évolution et crise de l'agriculture au Sahara. Dissertation, University of Paris I, France, 129 p.

20. Toutain G., 1979, Eléments d’agronomie saharienne, de la recherche au développement. Inra-Gret, Paris, France, 300 p.

21. Van Schaik C.P., Terborgh J.W. \& Wright S.J., 1993, The Phenology of Tropical Forests: Adaptive Significance and Consequences for Primary Consumers. Annual Review of Ecology and Systematics, 24, 353-377.

22. Wrigley G., 1995, Date Palm. In: Evolution of Crop Plants. Longman., London, Englend, England, pp 399-403.

23. Zaid A., 2010, The World date production: a challenging case study. Date Palm Research 
\& Development Programme, United Nations Office for Project Services/UNOPS, Al Ain, UAE, pp 902-915.

24. Zaid A. \& De Wet P.F., 2002, Botanical and systematic description of the date palm. FAO Plant Prod Prot., 156, 1-28.

25. Zohary D. \& Hopf M., 2000, Domestication of plants in the Old World. Oxford University Press, New York, USA, 316 p.

PDF généré automatiquement le 2023-04-26 11:01:31

Url de l'article : https://popups.uliege.be/2295-8010/index.php?id=1898 